\title{
プサー・チャー（カンボジア・プノンペン）にみる市場の空間構成 SPACE ORGANIZATION OF THE MARKET AS SEEN ON PHSAR CHAS, IN PHNOM PENH, CAMBODIA
}

\author{
脇田祥尚*, 川田叔生** \\ Yoshihisa WAKITA and Toshio KAWATA
}

The aim of this study is to clarify the space organization of Phsar Chas, old market in Phnom Penh, Cambodia. We conclude the results as below from the data mostly based on the field survey. Phsar Chas does not have rigid big building like an ordinary market. It is gathering of small shops without big building. 1.5 meter square is the basic form of the shops. The shop space is made by layout of equipments such as showcase, chairs and sewing machines. Flexibility is the feature of the shop spaces. The shop space is also for living. They talk, eat meal, sleep and play in the shop. Passage is used not only for movement but also for work and life. They work, wait for customers, talk, play and take a rest on passage. Passage has a function to accept activities and equipments which cannot be set on the shop space.

Keywords: Cambodia, Phnom Penh, Market, Space Organization カンボジア, プノンペン, 市場，空間構成

\section{1.はじめに}

\section{1-1 研究の背景・目的}

本研究は、カンボジアの首都プノンペン中心部に位置するプ サー・チャーPhsar Chasを対象に、市場の空間構成を明らかにする ことを目的とする。

プノンペンでは、1991年のパリ和平協定締結、1993年の王政復活 以降、急激な変化に見舞われ、近年急激な人口増加とともに、国内 外の資本による開発が急速に進められている。プノンペン特別市の 人口増加率は $2.82 \%$ （1998-2008）注1)、また都市成長率は4.6\% （2005-2010）注2）と高い值を示しており、開発圧力が大きいこと が伺える。2009年現在、高層の事務所建築や商業施設・娛楽施設な どが、従前の低層な建築群に代わって建てられつつある。

一方、プサー・チャーに代表されるように、屋台や簡易な施設に より構成される既存の市場は、ひととものとが混然一体と存在する と共に、周辺道路や隣接寸る街区ともつながりをもち、低容積なが らも都市に賑わいを与える要素として存続し続けている。

再開発が急激に進展する兆しをみせるプノンペンにおいて、建て 替えがしばしば取りざたされるプサー・チャーを対象に、地域の 人々の生活を支え賑わいの核として存在してきた市場の空間構成を 明らかにすることは、今後の開発の計画指針を得る上でも意義ある ものと考えることができる。

プノンペン市内には2009年現在13の市場が存在する注3)。プ サー・チャーはクメール語で古い市場を意味する。設置時期は定か でないが、1922年発行の地籍図には既に記載されており、プノンペ ンで最も古くからある市場である注4)。プノンペンで最も早くから
開発が進められたドンペン地区の中心部に位置する（図 1 ）。他の 市場が鉄筋コンクリート造のパーマネントな構造を伴っているのと 異なり、仮設性の高い空間構成となっている。一つの大きな建物の 中に店舗が入るのではなく、一つ一つの小規模な店舗の集合によっ て市場が形成されている点が大きな特徵である。

店舗は、それぞれの業態にあわせて改造されている。販売・業務 行為は、店舗内だけでなく通路も活用して行われている。そうした 活発な空間利用は、施設内部に留まらず、施設の外周部分あるいは 施設の外周道路でも見ることができる。プサー・チャーは、各店舗 に見られる自立的な空間形成を明らかにする上でも、また賑わいの 空間形成手法を明らかにする上でも興味深い対象と言える。

プノンペンの建築計画・都市計画に関する研究は、ポル・ポト支 配の影響ならびに内戦により散逸しており、カンボジア人研究者あ るいは植民地時代の宗主国であったフランスの研究者による1991年 以前の研究はみることができない。近年の研究も限られたものしか なく注5)、プノンペンの市場やプサー・チャーそのものを取り上げ た研究はない。

\section{1-2 調査方法}

本研究は、文献調查を踏まえながら、プノンペンの王立芸術大学 建築都市計画学科との合同現地調查にその成果の多くを依拠してい る。現地調查は、2006年 8 月 14 日〜 $９$ 月 1 日、2007年 8 月 8 日〜 23 日、2008年 8 月 6 日〜 23 日の 3 次にわたっている。第 1 次、第 2 次 の調査では概要把握ならびに予備調査を行った。本稿の分析に関わ る現地調査データは、第 3 次調查のデータを主にもとにしている。 調査内容は、実測、ヒアリング、参与観察である。各店舗の平面

本論文は参考文献12) 13)に，加筆・修正を加えたものである

* 近畿大学理工学部建築学科 准教授・博士 (工学)

** 近畿大学大学院総合理工学研究科環境系工学専攻

Assoc. Prof., Dept. of Architecture, School of Science and Technology, Kinki Univ., Dr. Eng. Graduate Student, Interdisciplinary Graduate School of Science and Engineering, Kinki Univ. 


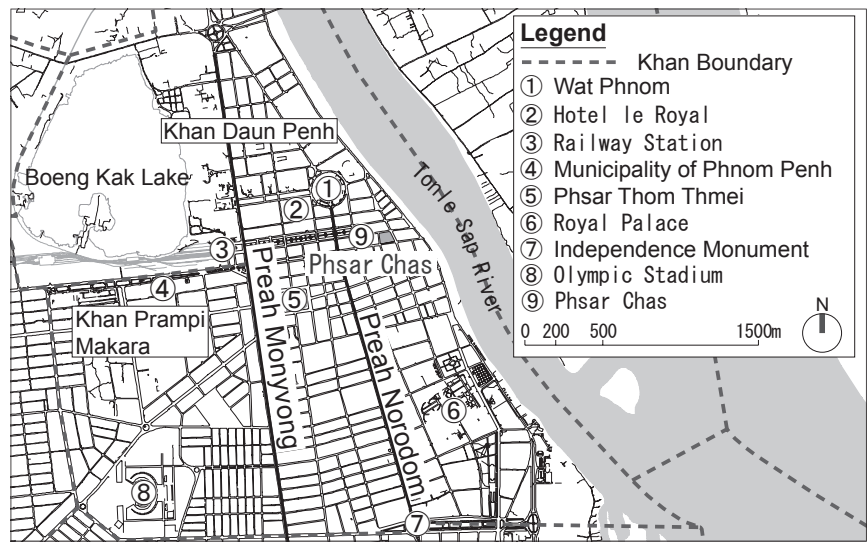

図 1 調查対象地の立地

図 ・断面図、店舗間の通路も含めた店舗群区画の平面図 ・物品配置 図、周辺道路における店舗配置図の実測を行った。また、店主や管 理事務所に対するヒアリングを行い、管理・運営方法等に関する情 報を収集した。

\section{2. プサー・チャーの概要}

\section{2-1 全体構成}

プサー・チャーは、南北 $70 \mathrm{~m}$ 、東西が北側 $70 \mathrm{~m}$ 、南側 $90 \mathrm{~m}$ 、面積 約 $5600 \mathrm{~m}^{2}$ の街区に形成されている。そのほとんどを店舗が占め、 651 店舗・17業種で構成される（図 2)。店舗以外の施設として は、中心部に管理事務所が配置され、南西部分にトイレが、南東部 分に機械室が設けられている。

管理事務所から北と南に抜ける通路は他の通路よりも幅が広く 3 $\mathrm{m}$ の幅員をもつ。他は概ね $2 \mathrm{~m}$ 前後の幅員である。通路はグリッド 状に計画されており、店舗も整然とした配置が基本となっている。
プサー・チャーの店舗には、Aタイプ〜Cタイプの 3 つの店舗形態 が確認できた注6）（図 3 ）。

Aタイプは、 $1.5 \mathrm{~m} \times 1.5 \mathrm{~m}$ の規模の店舗が田の字型に 4 つ配置さ れる形式である。 $3 \mathrm{~m} \times 3 \mathrm{~m}$ が 1 つのユニットを形成する。Bタイ プは、管理事務所の東西にそれぞれ 1 棟ずつ配置された $6 \mathrm{~m} \times 21 \mathrm{~m}$ の覆い屋を、 $3 \mathrm{~m} \times 3 \mathrm{~m}$ の規模で分割して店舗として活用する形式 である。Cタイプは、小規模店舗が横に連続する形式で、奥行き 1. 1〜 1. $2 \mathrm{~m}$ 、横幅 $21 \mathrm{~m} \sim 40 \mathrm{~m}$ の細長い建物を幅 $1.4 \sim 1.5 \mathrm{~m}$ ごとに分 割して店舗群として活用寸る形式である。後背部への拡張利用が可 能なタイプと背面を壁で仕切るタイプとを分け、C-1、C-2 とした。

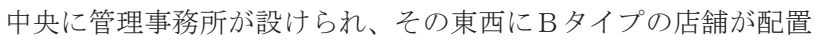
されている。街区の外周はC タイプの店舗で囲まれる。市場の主要

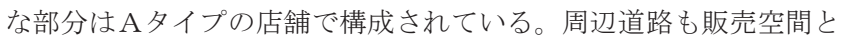
して活用される。特に、西側道路は店舗で埋め尽くされている。日 よけのためのパラソルを立て商品を並べ販売空間を形成している。

業種の分布には特徵がみられる。店舗数でいうと、貴金属 $(19 \%)$ 、衣類（15\%）、美容院（13\%）、生活雑貨（12\%）、生 鮮食品（ $8 \%$ ）を扱う店舗が目立って多い。生鮮食品は北西角に、 衣類は北東部分に、貴金属は中央西側に、美容院は中央東側ならび に南側に配置されるなど、同業種が集まって店舗が営まれている。

商品や備品は、営業時には店内ならびに通路上に陳列されるが、 閉店時には店舗内に収容される。

\section{2-2 管理方法}

管理事務所は1981年に設けられ、プノンペン市役所が管理を行っ ている。管理事務所には休業日はないが、個々の店舗ではそれぞれ 独自に休業日を設定している注7)。

多くの店舗が、それぞれの業態にあわせて改装されているが、改

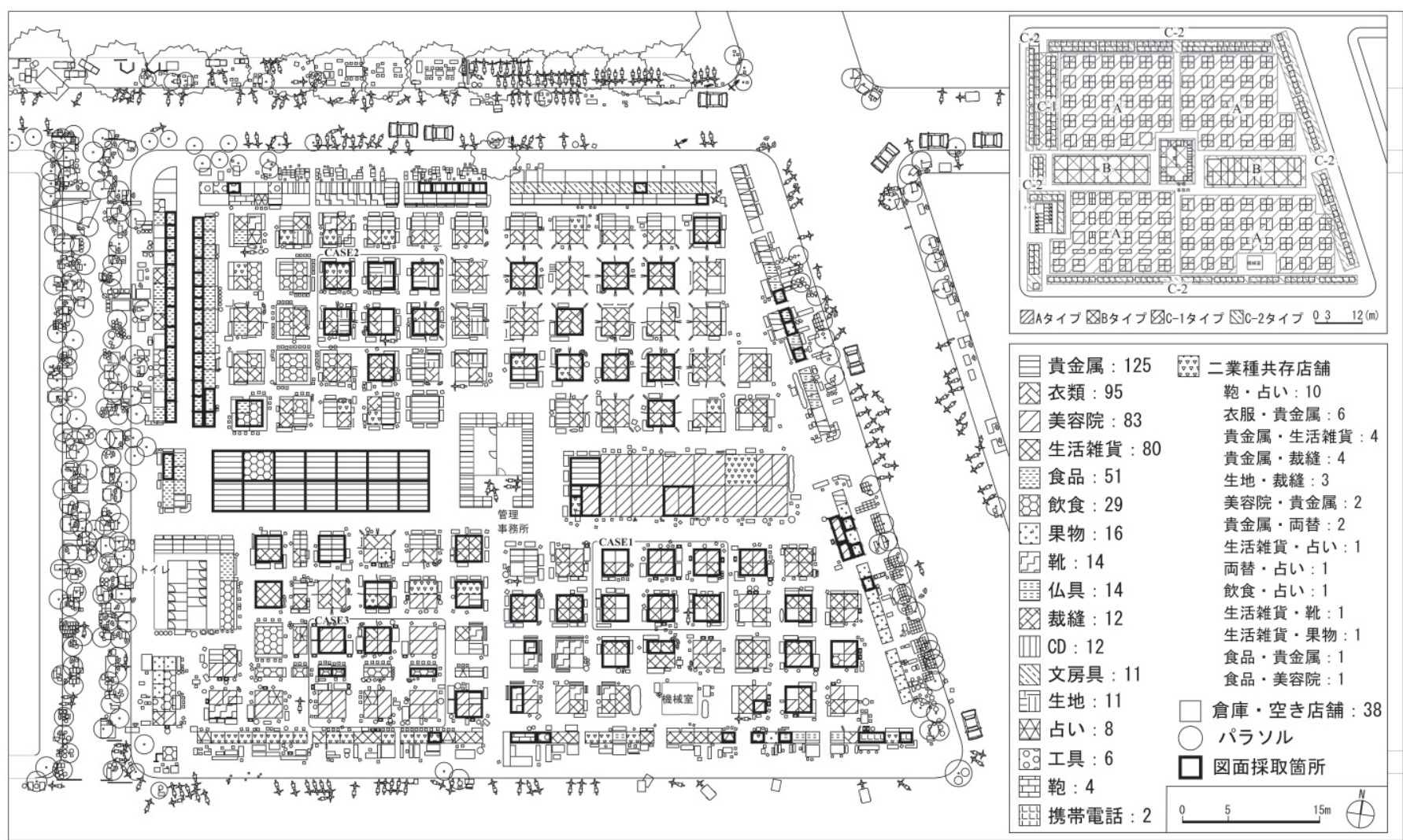

図 2 業種・物品配置図ならびに店舖形式分布図 
造・改装は管理事務所に許可を得てから行われる。店舗から通路に あふれ出して商品を設置している例を多数見ることができるが、こ れは周辺の理解のもとに許可されている。西側道路にパランルを立 て営業している店舗ならびに周辺道路で営業を行っている店舗も、 管理事務所の許可のもとに営業をおこなっている注8)

\section{3. 市場の空間形成手法}

\section{3-1 店舗空間の空間構成}

上述したA〜Cのタイプの中で最も数が多く、プサー・チャーの主 要部分に位置し、なおかつプサー・チャーを特徵づけるAタイプの 店舗について、その店舗空間の空間構成について考察を行う。

\section{（1）店舗の規模}

Aタイプの店舗は、 $1.5 \mathrm{~m} \times 1.5 \mathrm{~m}$ の規模を基本とし店舗が構成さ れているが、中には、隣接する店舗を統合するなどして、拡張して いる店舗も見られる。全 371 軒のうち、隣接する店舗を統合し、1.5 $\mathrm{m} \times 3 \mathrm{~m}$ の規模をもつ店舗が 33 軒、 4 分割されていた $3 \mathrm{~m} \times 3 \mathrm{~m}$ の ユニットすべてを統合し活用している店舗が 2 件みられた。前者 33 軒は、衣料11軒、美容院 11 軒、雑貨 5 軒、飲食 3 軒、生地 3 軒で あった。後者は飲食 1 軒、雑貨 1 軒であった。いずれも全体からす れば大きな割合ではなく、業種に関わらず $1.5 \mathrm{~m} \times 1.5 \mathrm{~m}$ の規模が順 守されているのがわかる。

\section{（2）店舗空間の実態}

各店舗は、 $1.5 \mathrm{~m} \times 1.5 \mathrm{~m}$ の均一な空間を活用して営業されてい る。図 4 ・図 5 より業種ごとに店舗の平面・断面構成がわかる。

Aタイプの店舗は、衣服（93軒）、美容院（64軒）、生活雑貨 （60軒）、貴金属（40軒）に多い。数は少ないが、飲食（16軒）、 靴（13軒）、裁縫（12軒）、生地（11軒）はすべてあるいはその多 くがAタイプの形式をとる。物品を持ち込んだり、高床を設けるな どして、多様な空間構成をとるが、いくつかの特徴がみられる。

台あるいは店舗内に増設された高床を利用して商品の陳列を行う ケースが多くみられる。衣服、靴、生活雑貨、生地の店舗がこの ケースに当てはまる。高さ $60 \sim 100 \mathrm{~cm}$ のレベルが陳列のスペースと して活用される。靴、生活雑貨の店舗では、商品を吊るす・立て掛 けるといった陳列方法がみられた。店員が店舗内に座りその前面女 るいは周囲の商品を販売するケースと、店員は店舗外に座り、店舗 内に陳列された商品を販売するケースがある。靴、生活雑貨の店舗 では、店舗外に店員がいる例が見られた。

また、高床を設けず、 $1.5 \mathrm{~m} \times 1.5 \mathrm{~m}$ の空間を作業空間として活用 寸るケースもある。美容院、裁縫の店舗がこれに該当する。前者で は洗髪台と美容椅子を配置することで作業スペースを形成する。後 者ではミシンを 2 台程度設置し作業スペースを形成する。

貴金属の店舗では、ショーケースを設置し対面式で販売を行う。 上記の陳列のケースと異なるのは、売り手と買い手の空間がショー ケースによって分離される点である。高床が設けられるケースとそ うでないケースがある。また、飲食店は周りをカウンターで囲い、 カウンター内で調理をするとともに、カウンターで客に食事をして もらう形式をとる。カウンター内は作業空間として機能し、店員と 客とはカウンターで空間的に分離される。

\section{(3) 店舗の空間構成}

以上の特徴を、Aタイプの店舗をもつ業種ごとに整理したのが表
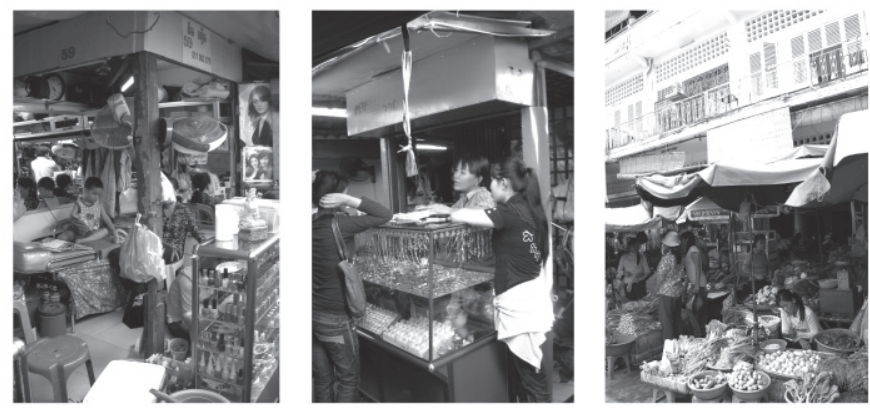

写真 $1 \mathrm{~A}$ タイプの店舗（左, 中央）パラソル店舗（右）

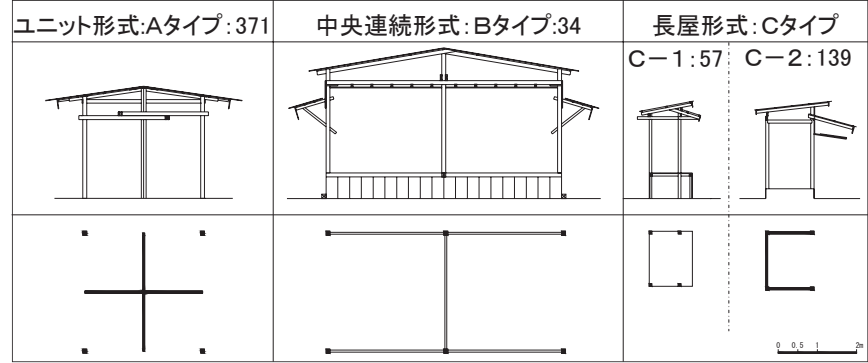

図 3 店舗の形式 (数值は店舗数)

表 1 Aタイプの業種別店舗空間の使い方

\begin{tabular}{|c|c|c|c|c|c|c|}
\hline 業種 & 店舗数 & 売り子の行為 & 客との関係 & 高床 & 設備 & 陳列方法 \\
\hline \multirow{2}{*}{ 衣類 } & \multirow{2}{*}{93} & \multirow{2}{*}{ 販売 } & 一体: 80 & $0: 70$ & \multirow{2}{*}{$\begin{array}{l}\text { 台、棚、ハンガー、マネ } \\
\text { キン }\end{array}$} & \multirow{2}{*}{$\begin{array}{l}\text { 重ねる、 } \\
\text { 吊るす }\end{array}$} \\
\hline & & & 分離: 13 & $x: 23$ & & \\
\hline \multirow{2}{*}{ 生活雑貨 } & \multirow{2}{*}{66} & \multirow{2}{*}{ 販売 } & 一体: 43 & $0: 43$ & \multirow{2}{*}{ 台、棚 } & \multirow{2}{*}{ 並べる } \\
\hline & & & 分離: 23 & $\times: 23$ & & \\
\hline 美容院 & 64 & 作業 & 一体 & $x$ & 洗髮台、美容椅子、 & - \\
\hline \multirow{2}{*}{ 貴金属 } & \multirow{2}{*}{40} & \multirow{2}{*}{ 販売 } & \multirow{2}{*}{ 分離 } & $0: 29$ & \multirow{2}{*}{ ショーケース } & \multirow{2}{*}{ 置く } \\
\hline & & & & $x: 11$ & & \\
\hline 飲食 & 29 & 作業 & 分離 & $x$ & カウンター、棚、コン & 並べる \\
\hline \multirow{2}{*}{ 靴 } & \multirow{2}{*}{13} & \multirow{2}{*}{ 販売 } & \multirow{2}{*}{ 一体 } & $0: 11$ & \multirow{2}{*}{ 棚、椅子 } & \multirow{2}{*}{ 掛ける } \\
\hline & & & & $x: 2$ & & \\
\hline 裁縫 & 12 & 作業 & - & $x$ & ミシン台 & - \\
\hline \multirow{2}{*}{ 生地 } & \multirow{2}{*}{11} & \multirow{2}{*}{ 販売 } & \multirow{2}{*}{ 分離 } & $0: 8$ & \multirow{2}{*}{ 台、棚 } & \multirow{2}{*}{$\begin{array}{l}\text { 重ねる、 } \\
\text { 吊るす }\end{array}$} \\
\hline & & & & $x: 3$ & & \\
\hline 占い & 4 & 作業 & 一体 & 0 & 椅子 & - \\
\hline \multirow{2}{*}{ 食品 } & \multirow{2}{*}{3} & \multirow{2}{*}{ 販売 } & \multirow{2}{*}{ 分離 } & $0: 1$ & \multirow{2}{*}{ 台 } & \multirow{2}{*}{ 並べる } \\
\hline & & & & $x: 2$ & & \\
\hline 果物 & 1 & 販売 & 分離 & $x$ & 発砲スチロール & 並べる \\
\hline
\end{tabular}

1 である。

もともとの躯体はいずれも同じであり、後の改造により高床を設 けているか設けていないかのみが躯体上の違いである。店舗数が 10 以上のもので言えば、美容院、飲食店、裁縫店はすべて高床が設け られていない。いずれも作業の場として店舗が活用されるが、美容 院、飲食店は店員が立って動き回るため高床が必要とされず、裁縫 店はミシン台で占められるため高床が必要とされない。その他の業 種では、高床が設けられるケースとそうでないケースがあり、店主 の啫好によるものだと考えられる。

店舗空間は、それぞれの業種に必要な設備・備品の配置によって 形成される。代表的なものとしては、飲食店ではカウンター、貴金 属の店舗ではショーケース、美容院では洗髪台や美容椅子、裁縫の 店舗ではミシンの設置によって店舗空間が形成される。

空間の使われ方は作業と販売に分けられ、販売の場合には、商品 は吊るす、立て掛ける、置く、重ねる、並べるといった陳列方法を とる。客が店舗内に足を踏み入れるケースはほとんどなく、美容院 のみがすべての店舗で店舗内に客のスペースが確保される。その他 の業種では、客は原則として店舗に入ることなく、通路から店員と やりとりすることになる。店舗は陳列と収納の場として機能し、店 


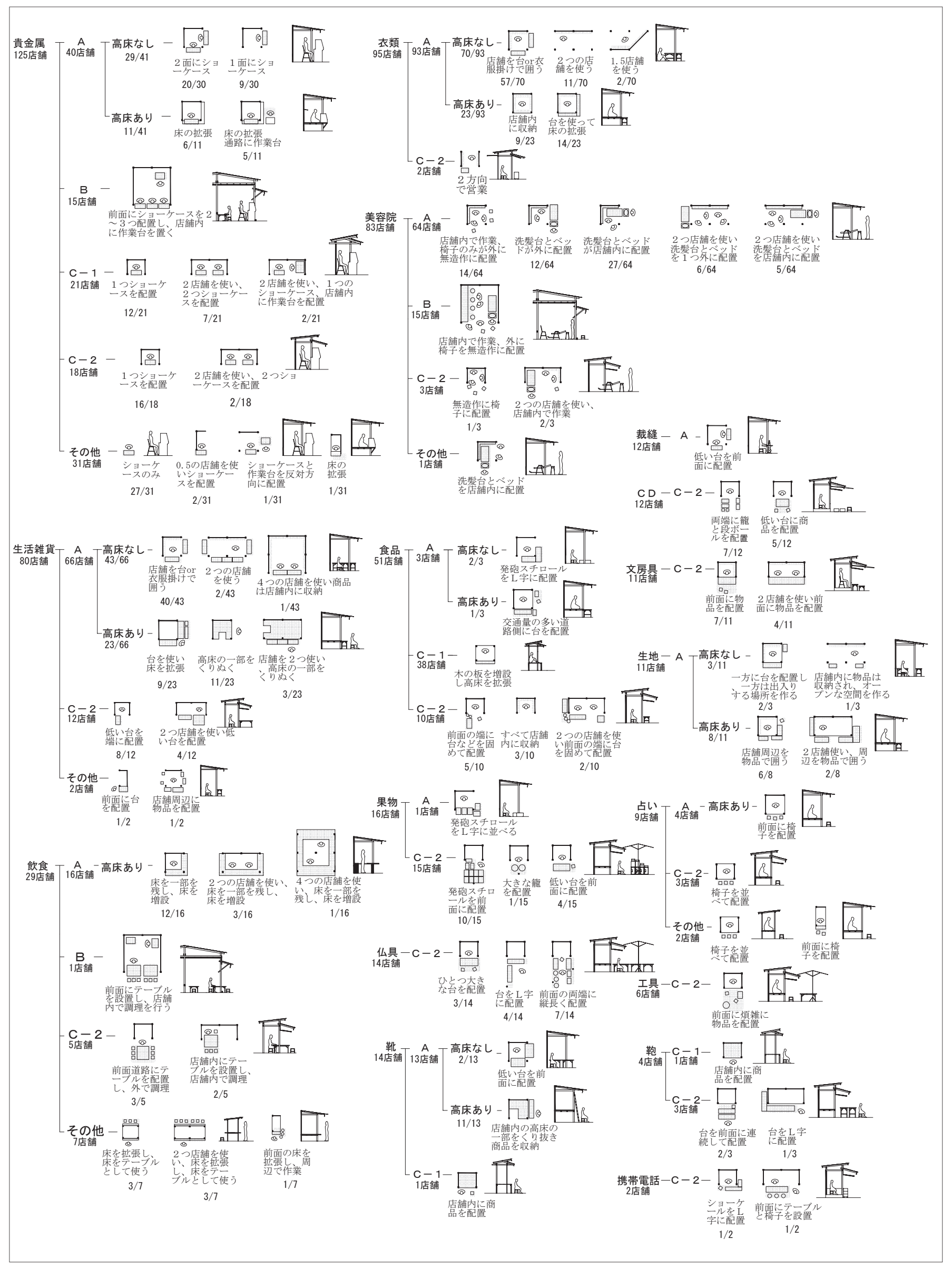

図4 業種別店舗空間の類型 


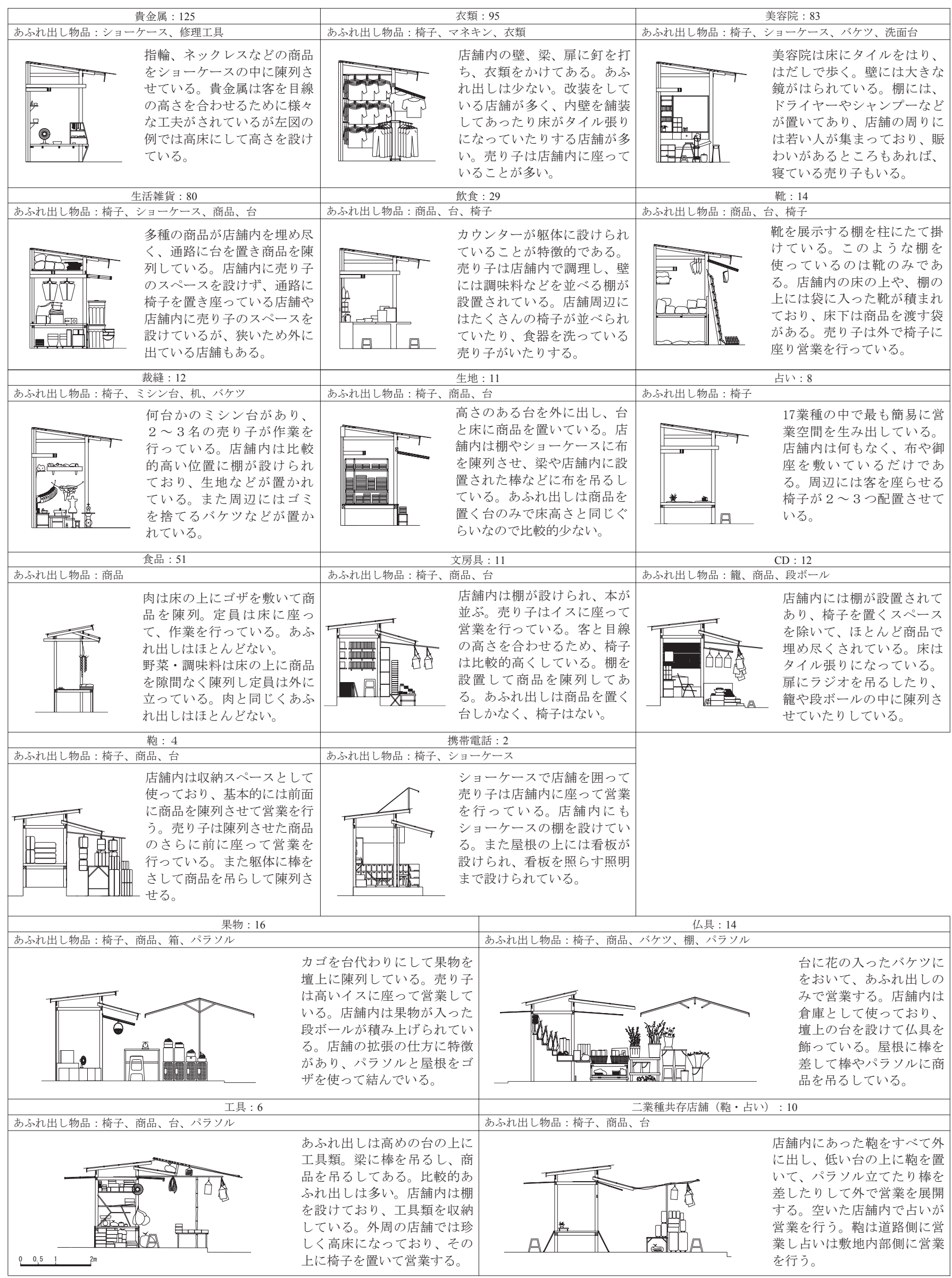

図 5 業種別断面構成 
員の手を介して商品は客にわたる。以上のように設備・備品や店員 の居場所によって、店員と客との関係が分離されるケースとそうで ないケースがある。貴金属の店舗や飲食店が分離の代表例である。

\section{3-2 店舗・通路の空間利用}

プサー・チャーでは、多くの物や行為は店舗内だけに収まること なく、店舗と店舗の間の空間、通路空間にあふれ出している。活発 な利用が行われていると考えられるエリアの中から 3 か所を選び、 その利用実態の分析を行う（図6）。

ケース 1 は、南東ブロックの一角で、美容院と生活雑貨店が混在 するエリアである。生活雑貨店では、商品陳列用の台と店員が腰掛 ける椅子が通路にあふれ出している。美容院では、洗髪台と美容椅 子ならびに店員あるいは客がネイルアート等の際に腰掛ける椅子が あふれ出している。閉店している店舗前面にバイクが置かれている 例が一件みられた。通路で見られる行為としては、ネイルアートの 作業や店舗の店番、向かいの店舗あるいは近くの店舗の人々との会 話やトランプゲームが挙げられる。

ケース 2 は、裁縫と生地の店舗が主に混在するエリアである。裁 縫の店舗では、裁縫作業のためのミシンが一部通路に設置されると ともに、客との打ち合わせ等に使われる椅子が置かれている。生地 の店舗では、商品陳列用の台が通路に設置される。閉店している店 舗の前には、使われていない台やバイクが置かれている。生地を販 売する際、店員は店舗内に居場所を形成するだけなく、店舗内す心゙ てを陳列空間とし店員は通路に居場所を設けるケースもみられる。 通りを挟んで向かいあう店員どうしが会話している例もみられる。

ケース 3 は、南西ブロックの一角で、美容院と飲食店を中心とし ながら、占いと衣料の店舗が 1 店舗ずつ存在するエリアである。飲 食店が一列に並んでいる。南側の通路は調理スペースとして使われ ている。北側の通路には椅子が並べられ、食事の場となっている。

\section{（1）通路の空間利用}

いずれの事例からも、通路の活発な利用が伺えるが、通路空間一 のあふれ出し物品を整理すると、主なものとして椅子（100件）、 商品（71件）、作業備品（67件）の 3 種類あることがわかる（表 2 )。店員が店番の際に座る椅子、飲食店の来客用の椅子、美容院 で爪の手入れをする際に使用される椅子が、通路にあふれ出してい る。いずれも居場所形成のためのものである。商品が陳列される台 や、貴金属や生活雑貨が入ったショーケース、衣類の展示ようのマ ネキンは、商品に該当する。洗髪台・美容椅子・美容器具、バケ ツ・鍋、ミシン台は作業備品に位置づけられる。その他として通勤 に使用するバイクが 2 件確認された。

関連して通路で行われる人々の行為を整理すると、通行、作業、 会話、遊び、店番、休噁の 6 種類があることがわかる。ミシンや美 容椅子が配置され、裁縫作業や理髪作業が通路で行われたり、飲食 店では調理の場として通路が機能する。また通路を介して向かい合 わ寸店の店員どうしのコミュニケーションの場となったり、近くの 店舗の人々が集まって談笑寸る場となっている。通路でトランプを している様子も観察された。店番のため通路に椅子を置いて客を 待ったり、ぼーっとする姿も見ることができた。これら 6 種類の行 為は、通行、業務、生活の 3 つに分けることができる。業務には、 作業と店番、生活には、会話、遊び、休嚊が該当する。

通路は、多くの物品があふれ出す場であるとともに、多くの行為

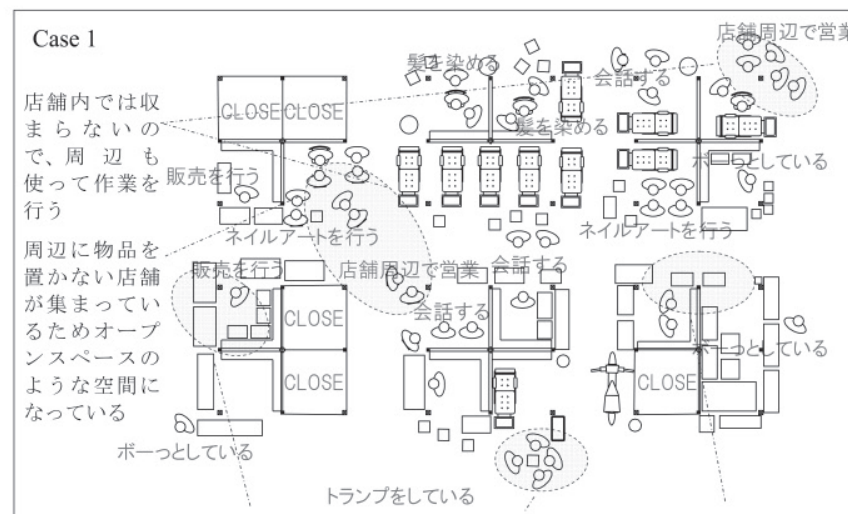

対角線上に営業を行うことで 周辺の売り子が集まって 営業方向に対しては小さな物品 面的な営業空間が生まれる 娛楽をして楽しんでいる を置き、店舗の中が見えるよう にしている

Case 2 営業方向が向き合うことに 対角に向かい合う売り子が会話するこ よって面的な空間が生まれる とによって通路空間に賑わいが生じる

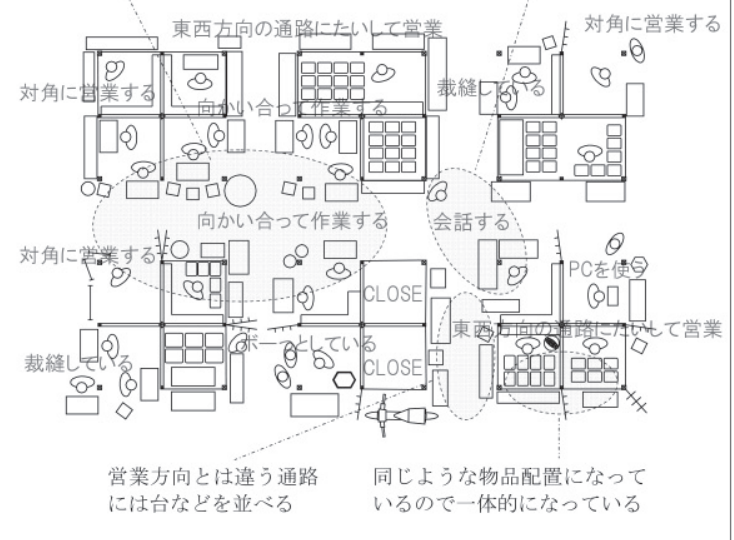

Case 3 美容院と衣服の商品やベットが 美容院の洗髪や髪染めな 飲食店が調理スペー 置かれている場となっている どの作業に使われている スとして使っている

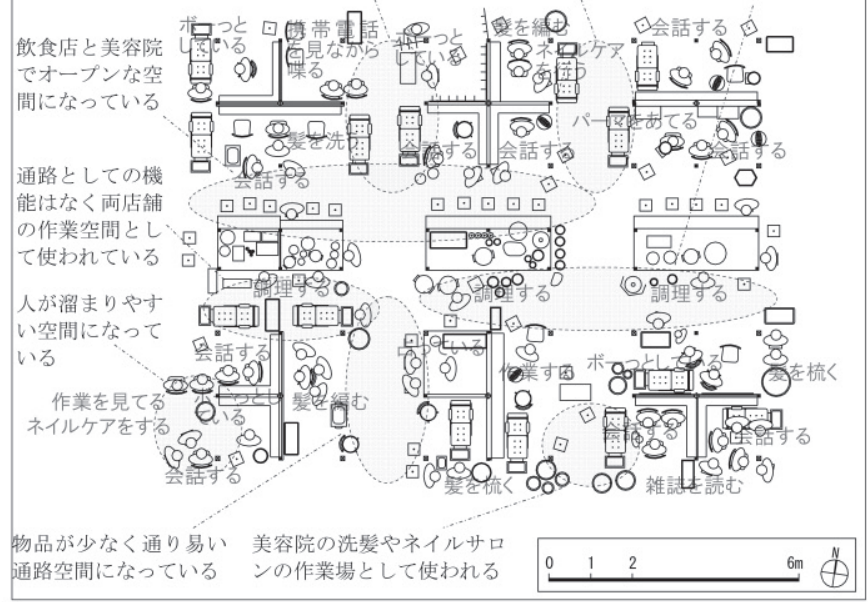

図 6 通路空間の空間利用事例

表 2 通路空間の物品数

椅子 台 ショーケース 洗髮台 $\mid$ 美容椅子 $\mid$ 美容器具 $\mid$ バケツ $\mid$ マネキン

\begin{tabular}{|l|r|r|r|r|r|r|r|r|r|r|r|}
\hline Case1 & 28 & 15 & 12 & 4 & 3 & 2 & 2 & 0 & 0 & 0 & 1 \\
\hline Case2 & 14 & 26 & 1 & 0 & 0 & 0 & 0 & 4 & 9 & 0 & 1 \\
\hline Case3 & 58 & 3 & 9 & 9 & 10 & 3 & 22 & 1 & 0 & 3 & 0 \\
\hline
\end{tabular}

が行われる場でもあることがわかる。 $1.5 \mathrm{~m} \times 1.5 \mathrm{~m}$ という狭小な店 舗ではまかない切れない行為や物品を受容する場として通路が機能 している。

\section{（2）店舗の空間利用 生活空間としての店舗}

3-1では業務空間として店舗をとらえたが、ケース $1 \sim 3$ の調査 
から店舗空間もまた生活空間としての役割を果たしていることがわ かる。会話、食事、就寝、遊びの場として店舗が使われる。食事 は、プサー・チャー内の飲食店から店舗に届けられ、食事後は食器 を通路脇に置いておけば回収される仕組みになっている。また美容 院の美容椅子で昼寝をするケースや、店舗内にハンモックをぶら下 げ、そこで昼寝をするケースも見られた。

\section{3-3＼cjkstart市場と街区の相互関係}

プサー・チャーは、市場の内部だけで施設が完結するのではな く、市場外周を巡る歩道の活発な利用ならびに西側道路の市場空間 への転用などを通じて、街区と密接な関係を築いている。

（1）市場外周部分の空間利用（表 3、図 7)

市場の外周にはCタイプの店舗が軒を連ねる。店舗面積が狭小な 上、前面に幅員 $2 \mathrm{~m} \sim 4 \mathrm{~m}$ の歩道が設けられているため、歩道への 商品のあふれ出しが多くみられる。車道に面する北・東・南側の外 周箇所には、105軒の店舗（うち 3 軒は閉店）がある。軒数の多い 業種は、果物（15軒）、仏具（14軒）、CD（13軒）、文具（12軒） である。それぞれ業種ごとに固まって配置されている。

Cタイプの店舗空間の利用内容を整理すると、収納、陳列、転 用、販売の 4 つに分けることができる。売り子の居場所によって 2 つに分けられる。売り子が店舗外にいるケースが、収納、陳列、転 用、売り子が店舗内にいるケースが販売である。

外周部分で最も店舗数の多い果物店は、収納に位置づけられる。 歩道上に、段ボールや発泡スチロールのケースで $120 \mathrm{~cm} \sim 180 \mathrm{c} \mathrm{m}$ の 台をひな壇状につくり、種類ごとに分けられた果物を山に盛って道 ゆく人々に対して陳列している。売り子は、陳列された果物の前 面、歩道上に座って店番をする。この際、Cタイプの構造体は、ひ な壇状の果物によって遮られ、道ゆく人々からは見えない。果物の 収納ケースを収納するスペースとして使われている。

Cタイプの構造体を陳列スペースとして活用するもので代表的な のが仏具店である。前面には、供え物である花がバケツ等に盛られ て配置され、奥に進むと、店舗内に様々な仏具が陳列されている。 売り子は、展示された仏具の前面スペースに座り、店番をする。

2 業種で店舗を共有するケースに該当するのが転用である。鞄販 売と占いとが店舗を共有するケースが最も多く 10 軒みられる。閉店 時は、商品である鞄や占いのための備品が店舗内に収納されている が、開店時には、店舗自体は、市場内の通路に向け占い店として機 能する。外周部分は、歩道上に鞄が配置され鞄屋となる。

その他、文具店やCD販売店などは、販売の事例になる。他事例と 同じように歩道部分へのあふれ出しがみられるが、店舗内に売り子 がおり、売り子の移動範囲も広くないため、あふれ出しも小さい。

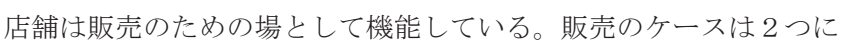
細分化され、文具店のように前面に商品を積み上げ売り子の移動範 囲を店舗内だけに限定するケースと、店舗外への移動経路を確保し ながら、前面の商品でゆるやかに店舗内と外部をつなぐケースがみ られる。

\section{（2）西側道路の空間利用（表 4、図 8)}

西側道路は、もともと市場の外周道路であるが、市役所の許可の もと自動車の通行を止めて、主に生鮮食品の売り場として機能して いる。長さ $70 \mathrm{~m}$ 、幅員 $7.3 \mathrm{~m}$ の道路を販売空間として使いかえてい る。現地調查によって 77 店舗存在することがわかった。それぞれ台
表 3 Cタイプの業種別店舗空間の使い力

\begin{tabular}{|c|c|c|c|c|}
\hline 使い方 & \multicolumn{4}{|c|}{ 業種 } \\
\hline 収納 & 果物: 15 & 鞄: 3 & & \\
\hline 陳列 & 仏具: 11 & 工具: 5 & & \\
\hline 転用 & 2業種共存: 17 & & & \\
\hline 販売 (open) & CD: 13 & 仏具: 3 & 占い:2 & 衣服:2 \\
\hline 販売(close) & 文房具: 12 & 貴金属: 10 & 生活雑貨:7 & 携帯電話: 2 \\
\hline
\end{tabular}

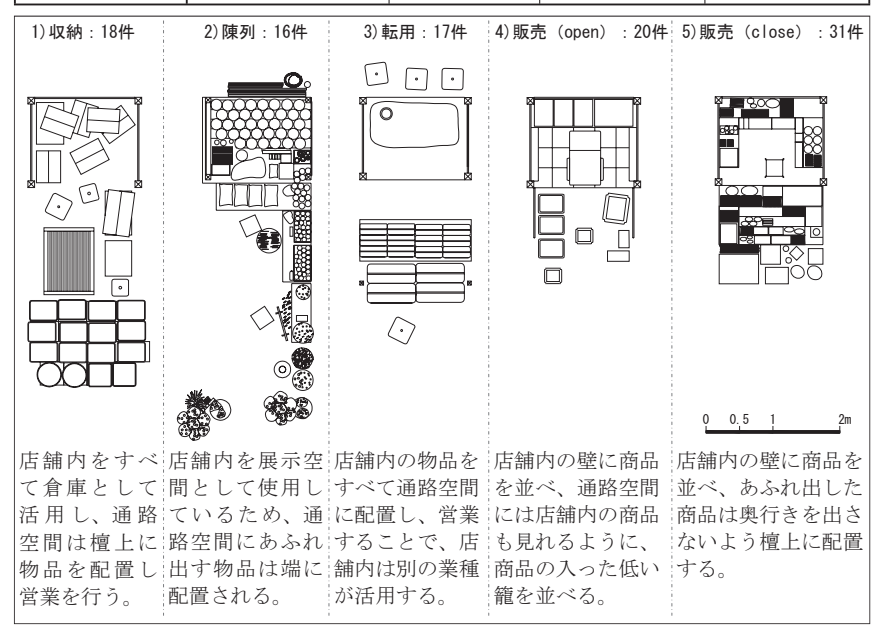

図 7 Cタイプの店舗空間の使い方の類型

表 4 店舗を構成する備品（単位：軒）

\begin{tabular}{|c|c|c|c|c|c|c|}
\hline 商品種別 & 籠 & 発砲スチロール & 台 & ステンレスの板 & 合計 & $\square$ \\
\hline 野菜 & 7 & 12 & 1 & & 20 & \\
\hline 果物 & 6 & 13 & 1 & & 20 & $1 .<$ \\
\hline 肉 & 1 & & 7 & 1 & 9 & 案办水为 \\
\hline 鮮魚 & 4 & & & 7 & 11 & \\
\hline 魚(干) & 1 & & 1 & & 2 & \\
\hline 飲料 & & & 2 & & 2 & \\
\hline 生活雑貨 & & & 2 & & 2 & \\
\hline $\begin{array}{l}\text { その他の } \\
\text { 食品 }\end{array}$ & 6 & & 2 & & 2 & o每 \\
\hline その他 & & & 3 & & 3 & $0.25 \quad 0.5 \quad 16$ \\
\hline 合計 & 25 & 25 & 19 & 8 & 77 & 図 8 果物の店舗事例 \\
\hline
\end{tabular}

やパラソルを用いて販売空間を形成している。鮮魚、精肉、野菜、 果物といった生鮮食品が77店舗中 60 店舗で扱われている。その他の 食品を扱う店舗が 12 店舗、生活雑貨を扱う店舗が 5 店舗みられた。 車道中央が買い物客の通路となり、車道の両側 $3 \mathrm{~m}$ 程度が販売空間 とされている。店舗の前後の重複などを考えずに、単純計算すれ ば、 $1.84 \mathrm{~m}$ に 1 店舗の割合で店舗が配置されていることになる。

店舗は、小規模なものでは、直径 $2 \mathrm{~m}$ のパラソルの下に、鮮魚や 野菜の並べられた直径 $30 \mathrm{~cm}$ の籠を 1 つ地面に置き、高さ $5 \mathrm{~cm}$ の木製 の椅子に売り子が腰掛け営業するものから、発砲スチロールの箱や プラスチックの箱、木製の露台や椅子やバケツで土台をつくり、 $70 \mathrm{~cm}$ 高さに発泡スチロールの箱を $3 \mathrm{~m} \times 4.5 \mathrm{~m}$ の規模に並べ、大 きな布を対角線上に立てたパラソルに結び営業を行う大規模なもの まで様々である。

パラソルと商品と椅子で売り場を形成する形式はいずれも同じで あるが、商品を設置するための設えに着目すると、4つあることが わかる。籠、ステンレスケース、台、発泡スチロールである。

精肉の店舗では、台の上にござを敷き、その上に並べて販売す る。売り子は台の上に乗り、座って作業をしながら販売するケース が多い。鮮魚は、ステンレスのケースか、籠にいれて扱われる。ス テンレスのケースは $90 \mathrm{~cm} \times 120 \mathrm{~cm}$ 程度のものが一般的で、下に椅子 やバケツなどを置き、 $50 \mathrm{~cm}$ 程度高さを確保する。籠が用いられるの は扱う商品が少ない場合が多く、直接地面に籠を置き販売してい 
る。果物の販売の際には、発砲スチロールが用いられるのが一般的 である。一つのケースに 1 種類の果物を入れ販売される。果物を扱 う店舗では、1 種類のみの果物を扱うケースはまれで、数多く並心゙ られた発砲スチロールのケースに多種の果物が並心゙られる。野菜は 籠に入れられ直に地面に置かれ販売されるか、発泡スチロールの ケースに種類ごとに並心゙られ販売される。

籠 1 つ分の商品だけで店舗の営業が可能であり、小規模な投資で も店を始めることが可能なことがわかる。店舗の設備は、いずれも 簡易なものであり、籠、ステンレスケース、発泡スチロール、台、 あるいはそれらを支える椅子、バケツならびに売り子が座る椅子、 日よけのパラソルで構成されている。小規模で柔軟な店舗構成が担 保されることで、 $70 \mathrm{~m}$ の間に 77 店舗の出店が可能になっている。

\section{4.まとめ}

本研究では、プノンペンでもっとも古くからある市場であるプ サー・チャーを対象として、店舗空間、通路空間、周辺道路の空間 構成・空間利用について分析を行い、市場の空間構成について明ら かにした。本論で得られた知見は以下の通りである。

1. 小規模空間の集積 多くの市場が、大規模な施設の中に小規模 な店舗が入る形式をとるのに対し、プサー・チャーは、小規模な店 舗でのみ構成される。店舗の空間構成は 3 つの形式に分けることが できる。中でも $1.5 \mathrm{~m} \times 1.5 \mathrm{~m}$ の店舗 4 つからなる $3 \mathrm{~m} \times 3 \mathrm{~m}$ のユ ニット店舗、 1 店舗の規模が $1.1 \mathrm{~m} \sim 1.2 \mathrm{~m} \times 1.4 \sim 1.5 \mathrm{~m}$ の連続店 舗、平均幅 $1.84 \mathrm{~m}$ の西側道路上の店舗といった小規模店舗の集積に よって市場が構成されている。

2.フレキシブルな空間形成 市場内の店舗空間では、 $1.5 \mathrm{~m} \times 1.5$ $\mathrm{m}$ の空間にショーケースや美容椅子、ミシンといった物品を配置す ることで、業務にあった空間にフレキシブルに作り替えている。外 周店舗では、狭小な店舗空間であっても、前面空間が確保される と、外部空間を居場所にして店舗そのものを、販売とは異なる機能 に使いかえているケースが半数を占める。収納、陳列、転用といっ た使い方がされる。西側道路の店舗は、いずれも簡易なものであ り、籠、ステンレスケース、発泡スチロール、台、あるいはそれら を支える椅子、バケツならびに売り子が座る椅子、日よけのパラソ ルで構成される。

3. 通路空間の活発な利用 通路空間は、通行のためだけではな く、業務、生活の場としても機能する。業務の場としては、作業や 店番の、生活の場としては、会話、遊び、休憩の場として機能す る。あふれれ出し物品は、居場所形成のための椅子、商品、作業備品 の 3 種類である。狭小な店舗でまかない切れない行為や物品を受容 する場として通路が機能している。

4. 生活空間としての店舗 店舗は、業務・販売の場としてだけで はなく、会話、食事、就寝、遊びの場としても機能している。

\section{参考文献}

1) カンボジア計画省統計局：カンボジア2008 年人ロセンサス（国勢調 査) 速報結果(暫定人口総数), 2008

2)「世界人口白書2008」国連人口基金（UNFPA）2008

3 ) 脇田祥尚, 白石英巨 : プノンペン(カンボジア)における都心街区の外部 空間利用, 日本建築学会計画系論文集, Vol. 73, No.631, pp. 19391945，2008. 9

4 ) 脇田祥尚, 白石英巨 : プノンペン(カンボジア)におけるショップハウス
の空間構成と街区構成に関する考察, 日本建築学会計画系論文集, No. 616 , pp. $7-14,2007.6$

5 ）大月敏雄：カンボジア・プノンペンの都市居住 スクウォッター地区の 住まいとまちづくり，彰国社，pp. 104-105， 2004

6 ) Michel Igout : Phnom Penh Then and Now, White Lotus Co., Ltd. 2001, Bangkok, Thailand

7) Vann Molyvann : Modern Khmer Cities, Reyum Publishing, 2003, Phnom Penh, Cambodia

8) Kep Chuktema, Jean Pierre Caffet, Roberto D' Agostino, Vincent Rotgé : Phnom Penh à 1' aube du xxie siècle, Atelier parisien d' urbanisme, 2003, Paris, France

9) Atelier parisien d'urbanisme, department des affaires internationales, Ministerè de la Culture : Phnom Penh développement ruban et patrimoine, 1997, Paris, France

1 o ) Helen Ross, Darryl Collins : Building Cambodia:' New Khmer Architecture' 1953-1970, The Key Publisher Company Ltd, 2006

1 1) Blancot C. \& Goldblum C. : Phnom Penh Seconde vie d' une capitale d'Asie du Sud-Est. Regards d' urbanistes, pp. 315-342, in : Bizot F. (ed.) Recherches nouvelles sur le Cambodge. Paris : Ecole française d' Extrême-Orient. 1994

12 ) 広畑大輔、白石英巨、脇田祥尚：プノンペン(カンボジア)における市 場の空間構成：オールド・マーケットを事例として, 日本建築学会中 国支部研究報告集 30, pp. 569-572，2007

１３）川田叔生，上段貴浩，脇田祥尚：プノンペン（カンボジア）における 土着的商業施設の空間構成に関する研究〜 Phsar Chasを事例として ，日本建築学会近畿支部研究報告集，2009

注

注 1 ）参考文献 1 )

注 2 ）参考文献 2 ）による。先進工業地域の平均が $0.5 \%$ 、開発途上地域の 平均が $2.5 \%$ である。

注 3 ）プノンペン特別市HPの記載による。

注 4 ）プノンペンに首都が移されたのは1866年である。1922年に発行された 地籍図には、4 4 の施設がプロットされているが、市場は一つのみで、 プサー・チャーの位置に中央市場の表記がみられる。1937年にフランス 人建築家によって設計された中央市場プサー・トゥメイPhsar Thmeiに対 して、その建設以前から存在した市場であるため、古い市場と呼ばれて いる。当時の状態がどの程度残っているかは不明である。

注 5 ) プノンペンの住環境改善に関寸る研究としては、参考文献 5 ) などが ある。フランス人研究者による研究は、参考文献 8）9）が挙げられ る。参考文献 6 ） は、プノンペンの都市形成史を知る上で貴重な概説書 である。カンボジア人建築家による都市研究としては参考文献 7 ）があ るが、各地の都市の事例研究であるが、概説にとどまっている。

注 6 ) 整然とした配置が建設当初からのものなのかどうかはわからないが、 参考文献１１）に掲載されたプサー・チャーの1956年の航空写真による と、Aタイプの店舗が現在に近いかたちで配置されているのがわかる。整 然とグリッド状に配置され中央には幅 $3 \mathrm{~m} \sim 4 \mathrm{~m}$ の通りが十字に設けら れている。自然発生的にこの形態をとったと考えるよりも、フランス統 治あるいは独立後の市役所の管理の中で、設置されたものと考えるのが 自然である。Bタイプ、Cタイプの店舗が写真に見られないことから、い ずれも1956年以降に設けられたものと考えられる。推論の域を出ない が、現在中央部に設けられているBタイプの建築物は、1956年以降、貴金 属の店舗をまとめるため等の目的で、再配置されたと考えられる。ま た、外周をとりまくCタイプの店舗は、自然発生的に設けられていた店舗 を再配置する目的で設置されたと考えられる。

注 7 ）店舗は市役所が所有権を有している。店舗を借りる場合、道路側に面 した店舗は年間81000リエル（1 ドルはおよそ4200リエル（2009）、面し ていない店舗は年間 45000 リエルを支払う。営業時間は、食品関係は午前 5 時〜午後 6 時、貴金属は午前8時〜午後 5 時、その他の店舗は午前 6 時〜午 後5時である。改装を行う際には事前に管理事務所への報告がいるがその 他の大きな規制はない。

注 8 ) 道路で営業を行う店舗の場所や規模の規定などは決められていない。

（2009年 7 月10日原稿受理，2009年11月24日採用決定） 